https://helda.helsinki.fi

\title{
Relations and Separations
}

\section{Green, Sarah}

2017-09

Green , S 2017 , ' Relations and Separations ' , American Anthropologist , vol. 119 , no. 3 , pp. 530-532 . https://doi.org/10.1111/aman.12918

http://hdl.handle.net/10138/223347

https://doi.org/10.1111/aman.12918

acceptedVersion

Downloaded from Helda, University of Helsinki institutional repository.

This is an electronic reprint of the original article.

This reprint may differ from the original in pagination and typographic detail.

Please cite the original version. 


\section{Relations and Separations}

Sarah Green

University of Helsinki, Finland

Sarah.green@helsinki.fi

Published in: American Anthropologist, 119:3, pp. 530-532 (2017), DOI 10.1111/aman.12918

The moment which persuaded me that demonstrations of xenophobic intolerance in Greece were turning into something sinister occurred on Sunday, October 28, 2012. It was a bright sunny morning in Athens, and my partner and I decided to take a walk on the hill below the Acropolis before flying to Helsinki. We passed by a group of three men playing music at the side of a wide stone path that gently wound its way up the hill. The music made a nice sound; I did not know what it was, but it fit the scene and added something to the atmosphere. The men, one older and two younger, looked like they came from some part of the eastern Mediterranean.

The moment was shattered less than a minute later, when two Greek men riding on a motorbike, dressed in black uniforms and waving a full-sized Greek flag on a pole, stopped in front of the musicians. Without getting off the motorbike, one of them said, in an official-sounding tone, "I thought we had this conversation with you yesterday?" The men stopped playing, their hands dropped to their sides, and their expressions switched from the broad, entreating smiles of street performers to the blank stares of people being interrogated. They did not meet the eyes of the men on the motorbike; they just stared ahead into space. "Didn't we have that conversation yesterday? $\underline{H U H}$ ?" That last word was shouted. The older man looked at the younger ones, nodded to them, and they began to pack their instruments away. The two men on the motorbike rode off, the one on the back waving the Greek flag.

I was shocked, not only at the incident, but also at my failure to intervene. I was in Athens to attend a workshop about the shifting politics of borders in the eastern peripheries of Europe, with 
a group of people, mostly anthropologists, who were planning a new research project on the subject. All of us knew about the rise in aggression, violence, and hatred towards others that was spreading across many parts of Europe, most particularly against people identified as undocumented migrants. We had spoken many times about it. And there I was, on the hill below the Acropolis, witnessing an example of such aggression, and I had been frozen to the spot. I was shocked that such a thing could happen so explicitly in broad daylight, with so many witnesses around; I was also shocked that the two Greek men behaved with the authority and confident swagger of police officers; and perhaps most of all, I was shocked at the fear they evoked in me. It crossed my mind to intervene, but I did not, for fear of their violence. With feelings of shame and confusion, I walked up to the musicians as they were finishing packing up, and put some money in their collection box, saying, in Greek and then in English, "This money is for your music. I am sorry about what just happened. Not everyone is like them. I hope you can continue to play again sometime." The older man nodded with a faint smile, put his hands together in thanks for the money, and walked away with the two younger men.

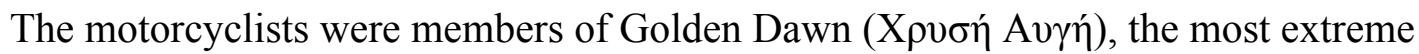
nationalist and anti-migrant political organization in Greece and probably in the whole of Europe. The members of Golden Dawn deliberately copy Nazi clothing, symbols and ideologies, and they explicitly condone violence against what they see as a threat to their nation, the Greek nation. They see themselves, as many such people across the world do, as the defenders of their nation. There are some women who support the group, but almost all of those who patrol the streets as vigilantes are men. Still, it was a little unusual for them to be carrying a full-sized flag on a motorbike. That was probably because they were returning from a march celebrating $O \chi l$ day (literally, "the day of No"). October 28, 1940 was the day when the Greek government, under the leadership of the dictator General Ioannis Metaxas (1936-1941), rejected an ultimatum from the Italian government to cede to Italy or be invaded (Clogg 1992: 120-121). Metaxas said No, which prompted an invasion from Italy and brought Greece into the Second World War. For members of Golden Dawn, it is a special 
day, given that the man who said No to a foreign invader held political beliefs very similar to their own.

Those kinds of nationalists are self-evidently anti-democratic, despite regularly standing for office and occasionally getting elected. Currently, the Golden Dawn Party has 18 elected members in the Greek parliament, three members of the European Parliament (despite being against the European Union), and 26 elected officials in Greek regional governments. There are other antiEuropean parties such as the United Kingdom Independence Party (UKIP), the France's Front National under Marine Le Pen (who currently has a realistic chance of being elected the next President of France), and the Lega Nord (Northern League) of Italy, which is both anti-European and campaigns for independence from the southern half of Italy. The main characteristics that such political parties have in common is that they want their country to leave the European Union (EU), believing that the EU is an evil force that costs the taxpayers huge amounts of money; they believe that migrants are bad, and should be both expelled and prevented from moving into the nation; and they believe that there are constant external threats, both physical (such as those embodied by the figures of drug smugglers and terrorists) and ideological (e.g. political correctness on the one hand, and different religious faiths on the other) that need to be vigilantly protected against. Strong and exclusively controlled borders is a hallmark of these kinds of politics.

Such ideals are the polar opposite of the thinking behind the creation of the European Union. Two of the most important of the EU's stated core principles are, first, that there should be "an ever closer union among the peoples of Europe"; and, second, that efforts should be made to address territorial inequalities evident across the different regions of Europe. ${ }^{1}$ Obviously, neither of those ideals are doing too well just now. The peoples of Europe seem to be moving ever further apart, with one of the most dramatic examples of that being the "Brexit" referendum, in which a majority of the British population voted to leave the European Union (Green 2016). Also, the agreement which was supposed to remove borders within the EU (the Schengen Agreement, which 
Britain never joined), is currently suspended in many places because of the enormous pressure put on it by the movement of millions of refugees and other undocumented migrants across the EU member states' territories during 2015 and parts of 2016. And what has been called the European Social Model, which has guided the idea of progressive economic, social, and employment policies in Europe, aiming to balance economic interests against social ones, is under severe pressure (Barbier, Rogowski, \& Colomb, 2015; Dølvik \& Martin, 2015; Vaughan-Whitehead, 2015; Whyman, Baimbridge, \& Mullen, 2012). ${ }^{2}$ Overall, it seems like the forces pulling things apart are becoming ever stronger than those which are pulling them together.

It is all the more important within the current situation in Europe to be clear about the different forms of the centrifugal forces in existence, because not all claims to autonomy are of the nationalist, xenophobic, protectionist kind. While parties such as Golden Dawn and UKIP want to destroy the European Union, other parties, such as the Scottish National Party, the New Flemish Alliance, and Nova Esquerra Catalana (based in Catalonia, in northern Spain), have the opposite intentions. Those movements, although all campaign for autonomy from their current state governments (United Kingdom, Belgium and Spain respectively), they are also firmly in favor of European Union membership. Famously, the Scottish electorate voted 62\% in favor of remaining in the EU in the Brexit referendum, ${ }^{3}$ and their parliament is currently led by the Scottish National Party, which wants Scottish independence from the UK. This is nothing like ethno-nationalist politics.

There is a very significant difference between politics which claim rights on the basis of identity - ethnic identity, autochthony, national identity - and those which claim rights to self-rule, rights to establish a polity in which the people of that polity can organize their own affairs. The first one, the more ethno-nationalist claim to rights, places an accent on origins, and identifies particular people who belong. That approach inevitably is against, and excludes, all others. The second one 
emphasizes the polity, the right to self-rule, and is about how you organize your affairs, not about a We against a Them (Pulkkinen 2001).

This conceptual difference is absolutely crucial to understand, even though both elements often co-exist within certain political movements. There can be claims to autonomy which are not automatically exclusionary and protectionist; which would not wish to build walls, or encourage hate speech against others, or which see threats everywhere. On the contrary, there are political autonomy movements within Europe that openly welcome close collaboration and partnership with others, and this is a central part of their politics. In the European Parliament, several of the political parties that campaign for autonomy from their current governments are highly active European Union supporters; several are also active in the environmentalist movement (which tends to involve cross-border alliances for obvious reasons). Indeed, one of the main political groupings in the EU Parliament is called the Greens-European Free Alliance, and it involves collaboration between most of the Green/environmentalist parties and several of the regional autonomy parties, such as the Party of the Corsican Nation and the Scottish National Party. ${ }^{4}$ These parties can easily be called "national" and part of the drive towards greater separation; but they are not separatist, and they are not ethno-nationalist in the manner of Golden Dawn.

This difference is one that anthropologists easily recognize. It is the difference between an ethnicist vision of belonging, in which people belong because of some claim to a similarity in their origins (Stolcke 1995); and what could be called a kinship vision of belonging, in which people belong because of a set of rules that establishes the relationship between one person and another, and in which the rules include ways to create new relations with other groups - most significantly, through marriage (Strathern 2011). The first one, the ethnicist approach, is fundamentally inwardlooking; the second, the kinship approach, is based on rules rather than origins and is outwardlooking. Understanding that not all relations, and not all separations, are the same is going to be crucial in the next few years. 



\section{References Cited}

Barbier, J.-C. e., Rogowski, R. e., \& Colomb, F. e. (Eds.). (2015). The sustainability of the European social model: EU governance, social protection and employment policies in Europe. Cheltenham: Edward Elgar Publishing Inc.

Clogg, R. (1992). A Concise History of Greece. Cambridge: Cambridge University Press.

Dølvik, J. E., \& Martin, A. (Eds.). (2015). European social models from crisis to crisis: employment and inequality in the era of monetary integration (First Edition. ed.).

Green, S. (2016). Brexit referendum: first reactions from anthropology. Social Anthropology/Anthropologie Sociale, 24(4), 478-502. doi:http://dx.doi.org/10.1111/14698676.12331

Pulkkinen, T. (2001). Nations within Nations - Nationalism and Identity Politics. In F. R. Dallmayr \& J. M.Rosales (Eds.), Beyond Nationalism? Sovereignty and Citizenship (pp. 43-56). Lanham, MD-Oxford: Lexington Books.

Stolcke, V. (1995). Talking Culture - New Boundaries, New Rhetorics of Exclusion in Europe. Current Anthropology, 36(1), 1-24.

Strathern, M. (2011). Binary License. Common Knowledge, 17(1), 87-103. doi:10.1215/0961754x2010-040

Vaughan-Whitehead, D. (Ed.) (2015). The European social model in crisis: is Europe losing its soul? Cheltenham, Glos.: Edward Elgar.

Whyman, P., Baimbridge, M., \& Mullen, A. (Eds.). (2012). The political economy of the European social model. New York: Routledge.

\footnotetext{
${ }^{1}$ This was even in the Treaty of Rome (1957): "to eliminate the barriers which divide Europe"; "reducing the differences existing between the various regions."

${ }^{2}$ Even the 'ever closer union' phrase has been repeatedly questioned, and is currently being debated in relation to the possible British exit from the European Union (http://www.economist.com/news/britain/21676749-does-europeantreaty-commitment-matter-why-david-cameron-wants-exemption-ever-closer - last accessed 29.1.2016).

${ }^{3}$ http://www.electoralcommission.org.uk/find-information-by-subject/elections-and-referendums/upcoming-electionsand-referendums/eu-referendum/electorate-and-count-information

${ }^{4}$ https://en.wikipedia.org/wiki/Greens\%E2\%80\%93European Free Alliance
} 